\title{
Metformin induces apoptosis and inhibits migration by activating the AMPK/p53 axis and suppressing PI3K/AKT signaling in human cervical cancer cells
}

\author{
YA-HUI CHEN ${ }^{1,2}$, SHUN-FA YANG ${ }^{1,3,4}$, CHUEH-KO YANG $^{2}$, HORNG-DER TSAI $^{5}$, \\ TZE-HO CHEN ${ }^{5}$, MING-CHIH CHOU ${ }^{1,3}$ and YI-HSUAN HSIAO ${ }^{1-3,5}$ \\ ${ }^{1}$ Institute of Medicine, Chung Shan Medical University, Taichung 40201; ${ }^{2}$ Women's Health Research \\ Laboratory, Changhua Christian Hospital, Changhua 500; ${ }^{3}$ School of Medicine, Chung Shan Medical University; \\ ${ }^{4}$ Department of Medical Research, Chung Shan Medical University Hospital, Taichung 40201; \\ ${ }^{5}$ Department of Obstetrics and Gynecology, Changhua Christian Hospital, Changhua 500, Taiwan, R.O.C.
}

Received May 15, 2020; Accepted October 30, 2020

DOI: $10.3892 / \mathrm{mmr} .2020 .11725$

\begin{abstract}
Human cervical cancer is the fourth most common malignancy among women worldwide, and it is expected to result in 460,000 deaths per year by 2040 . Moreover, patients with cervical cancer often display drug resistance and severe side effects; therefore, the development of effective novel chemotherapeutic agents is important. In the present study, the effects of metformin, a first-line therapeutic drug for type 2 diabetes mellitus, were evaluated in cervical cancer. Compared with the control group, metformin significantly inhibited cell viability and migration, and induced apoptosis and cell cycle arrest in human cervical cancer cell lines (CaSki and HeLa). Following metformin treatment, the protein expression levels of p-AMP-activated protein kinase (p-AMPK), which promotes cell death, and the tumor suppressor protein p-p53 were remarkably upregulated in CaSki and C33A cells compared with the control group. Furthermore, compared with the control group, metformin significantly suppressed the PI3K/AKT signaling pathway in CaSki, C33A and HeLa cells. Compound $\mathrm{C}$ (an AMPK inhibitor) significantly reversed the effects of metformin on CaSki, C33A and HeLa cell viability, and AMPK and p53 phosphorylation. The results of the present study suggested that metformin induced AMPK-mediated apoptosis, thus metformin may serve as a chemotherapeutic agent for human cervical cancer.
\end{abstract}

Correspondence to: Dr Yi-Hsuan Hsiao, Department of Obstetrics and Gynecology, Changhua Christian Hospital, 135 Nanhsiao Street, Changhua 500, Taiwan, R.O.C.

E-mail: 54315@cch.org.tw

Key words: metformin, apoptosis, migration, AMPK-activated protein kinase/p53, PI3K/AKT, cervical cancer

\section{Introduction}

Cervical cancer is the fourth most common malignancy in women worldwide, resulting in considerable economic and medical burden within society (1). Cervical cancer is a global public health issue (1) with the number of associated deaths per year estimated to reach 460,000 by 2040 (2). Cervical cancer treatment typically includes surgery, chemotherapy and radiotherapy; however, the treatment strategies are not always sufficient (3). Various chemical drugs, such as bevacizumab, topotecan hydrochloride and gemcitabine/cisplatin, are the first-line treatments used in cervical cancer chemotherapy; however, patients often display severe side effects and drug resistance, resulting in tumor recurrence and further progression $(4,5)$. Therefore, improving the current understanding of the biological properties of cervical cancer cells and developing effective novel chemotherapeutic agents is important.

Metformin, a biguanide derivative approved by the US Food and Drug Administration, is a well-tolerated first-line therapy for type 2 diabetes mellitus (6). Clinical and laboratory studies have demonstrated that metformin inhibits cellular proliferation, and induces apoptosis and cell cycle arrest in vitro (7-13). Moreover, metformin reduced the growth of experimental tumors in vivo, including in prostate, lung, breast, colon and pancreatic cancer, as well as in oral squamous cell carcinoma and melanoma (7-13). Moreover, several studies have reported that in cancer therapeutics, metformin exerts its effects via several molecular signaling pathways, including the AMP-activated protein kinase (AMPK), mTOR, insulin-like growth factor-1, JNK/p38 MAPK, human epidermal growth factor receptor-2 and NF- $\kappa B$ signaling pathways (14-20). However, Kowall et al (21) and Iliopoulos et al (22) revealed that when used alone, metformin is not an effective anticancer treatment for colorectal, lung, breast or prostate cancer; however, when combined with multiple chemotherapeutic agents, metformin can effectively reduce tumor progression in various types of cancer. In vitro and in vivo studies have indicated that 
when combined with caffeic acid or nelfinavir, metformin synergistically inhibits cancer cell proliferation and tumor growth $(23,24)$. The combined use of metformin and chemotherapeutics (including, gemcitabine, paclitaxel/carboplatin, megestrol acetate and erlotinib) is being investigated in several ongoing phase I/II clinical trials (clinicaltrials. gov) to assess whether these combinations increase patient survival and inhibit pancreatic (NCT02005419), ovarian (NCT02312261), endometrial (NCT01968317) and breast cancer metastasis (NCT01650506).

Pollak (25) revealed that the antineoplastic mechanisms underlying metformin may display indirect and/or direct effects on cancer biology. Indirectly, metformin binds components of respiratory complex I to limit mitochondrial oxidative phosphorylation, resulting in induced hepatic energy stress and reduced liver gluconeogenesis, which ultimately leads to a decrease in circulating glucose and insulin levels, and in turn may inhibit tumor growth in patients with insulin-responsive cancer (26). Regarding its direct effects on cancer, metformin may adequately accumulate in neoplastic tissues resulting in reduced ATP production, which triggers AMPK activation, but inhibits mTOR and fatty acid synthases expression, ultimately reducing cellular energy consumption and promoting energetic stress, resulting in tumor cell death $(27,28)$. Another study revealed that metformin reduces ATP production, which when coupled with the loss of AMPK, p53 or liver kinase B1 (LKB1) function, energy deficient tumor cells may not exhibit a high compensatory rate of glycolysis, resulting in a lethal energetic crisis and cytotoxic effects (29-31). Thus, understanding the mechanisms underlying the therapeutic effects of metformin is crucial for the development of potential cervical cancer therapies.

$\mathrm{AKT}$ is a serine/threonine kinase with a key role in the PI3K/AKT signaling pathway, which mediates various biological functions, including cell survival, proliferation, apoptosis, angiogenesis, glucose metabolism, mitochondrial membrane gradient and protein synthesis $(32,33)$. Increased AKT activity has been reported in $30-50 \%$ of breast, ovarian, prostate and pancreatic cancer tumors $(34,35)$. The results of clinical studies indicated that the levels of phosphorylated (p)-AKT were also high in esophageal squamous cell carcinoma $(90.4 \%)$, lung cancer $(76.4 \%)$ and breast cancer (20-26\%), which often resulted in drug resistance and lower patient survival rates $(36-40)$. In the present study, the anticancer mechanisms underlying metformin were evaluated by performing an apoptosis assay, and the activation of the AMPK/p53 and PI3K/AKT signaling pathways in human cervical cancer cell lines (CaSki, C33A and HeLa) following metformin treatment were evaluated.

\section{Materials and methods}

Cell line and culture. The CaSki, HeLa and C33A human cervical cancer cell lines were purchased from the Bioresource Collection and Research Center. CaSki cells were cultured in RPMI-1640 (BioConcept AG) and HeLa and C33A cells were cultured in Eagle's minimum essential medium (MEM; HyClone: Cytiva) supplemented with $10 \%$ fetal bovine serum (FBS; HyClone: Cytiva) in a humidified incubator at $37^{\circ} \mathrm{C}$ with $5 \% \mathrm{CO}_{2}$, respectively.
Cell viability assay. Cells were seeded into a 96-well plate ( $2 \times 10^{4}$ cells/well) in RPMI-1640 or MEM. Subsequently, cells were pre-treated with or without Compound C (an AMPK inhibitor; Merck $\mathrm{KGaA}$ ) for $2 \mathrm{~h}$ at $37^{\circ} \mathrm{C}$, CaSki and $\mathrm{C} 33 \mathrm{~A}$ were cells treated with $1 \mu \mathrm{M}$ Compound $\mathrm{C}$ and HeLa cells were treated with $5 \mu \mathrm{M}$ Compound $\mathrm{C}$, followed by treatment with metformin (0-20 mM; Cayman Chemical Company) for $48 \mathrm{~h}$ at $37^{\circ} \mathrm{C}$. Following treatment, $10 \mu \mathrm{l}$ Cell Counting Kit-8 (CCK-8) solution (Dojindo Molecular Technologies, Inc.) was added to each well and incubated at $37^{\circ} \mathrm{C}$ for $1 \mathrm{~h}$. Absorbance was measured at a wavelength of $450 \mathrm{~nm}$ using a FLUOstar Galaxy microplate reader (BMG Labtech $\mathrm{GmbH}$ ).

Migration assay. Cell migration was assessed by performing a Transwell migration assay using Transwell chambers (24-well inserts; 8.0-micron PET; BD Biosciences). Cells were seeded $\left(2 \times 10^{4}\right.$ cells/well $)$ into the upper chamber in serum-free RPMI-1640 or MEM medium containing 0,5 or $10 \mathrm{mM}$ metformin; these concentrations of metformin having been selected based on the cell viability assay test. The lower chamber was filled with $700 \mu 1$ RPMI-1640 or MEM medium supplemented with $10 \%$ FBS. Following incubation for $48 \mathrm{~h}$ at $37^{\circ} \mathrm{C}$, a wet cotton swab was used to remove the non-migratory cells from the upper surface of the Transwell membrane. Subsequently, migratory cells were fixed with $3.7 \%$ formalin for $2 \mathrm{~min}$ and $100 \%$ methanol for $20 \mathrm{~min}$ at room temperature (RT). Migratory cells were stained with $0.1 \%$ crystal violet for 20 min at RT and observed using a BX61 fluorescence microscope (magnification, x100; Olympus Corporation).

Apoptosis and cell cycle analyses. Apoptosis and cell cycle analyses were performed using an FITC Annexin V Apoptosis Detection kit (BD Biosciences) and PI/RNase staining buffer (BD Pharmingen; BD Biosciences), respectively, according to manufacturer's instructions. Cells were seeded ( $1 \times 10^{6}$ cells/well) into 6 -well plates and treated with 0,5 or $10 \mathrm{mM}$ metformin for $48 \mathrm{~h}$ at $37^{\circ} \mathrm{C}$. Subsequently, cells were collected, fixed with cold $70 \%$ ethanol at room temperature and stored at $-20^{\circ} \mathrm{C}$ until analysis. Prior to analysis, cells were centrifuged at $400 \mathrm{x} \mathrm{g}$ for $10 \mathrm{~min}$ at $4^{\circ} \mathrm{C}$ and washed with cold PBS. For cell cycle analysis, cells were stained with $0.5 \mathrm{ml} \mathrm{PI} / \mathrm{RNase}$ staining buffer for $15 \mathrm{~min}$ at RT in the dark. For apoptosis analysis, cells were double-stained with $5 \mu \mathrm{l}$ Annexin V-FITC and $5 \mu \mathrm{l}$ PI for $15 \mathrm{~min}$ at RT in the dark. Stained cells were analyzed using a Cytomics FC500 flow cytometer (Beckman Coulter, Inc.), CXP software (version 2.3; Beckman Coulter, Inc.) and late apoptosis was assessed.

Western blotting. Cells were seeded $\left(2 \times 10^{6}\right.$ cells/dish) into 10-cm dishes, pre-treated with or without Compound $\mathrm{C}$ (1 or $5 \mu \mathrm{M}$ ) for $2 \mathrm{~h}$ at $37^{\circ} \mathrm{C}$ and incubated with 0,5 or $10 \mathrm{mM}$ metformin for $48 \mathrm{~h}$ at $37^{\circ} \mathrm{C}$. Total protein was isolated from cells using RIPA buffer (EMD Millipore) and protein concentrations were determined using a BCA protein assay kit (Thermo Fisher Scientific, Inc.). Proteins (30 $\mu \mathrm{g})$ were incubated at $95^{\circ} \mathrm{C}$ for $10 \mathrm{~min}$, separated via $10-12 \%$ SDS-PAGE and transferred to $0.2-\mu \mathrm{m}$ PVDF membranes (Bio-Rad Laboratories, Inc.). Following blocking with BlockPRO blocking buffer (Energenesis Biomedical Co., Ltd.) for $1 \mathrm{~h}$ at room temperature, the membranes were incubated 


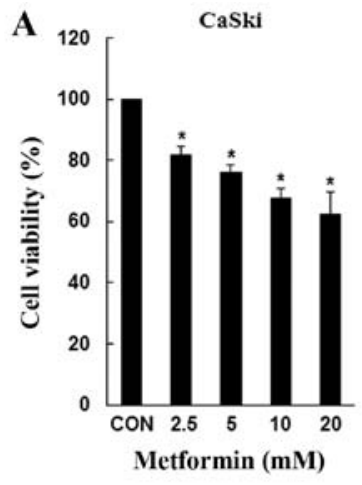

B
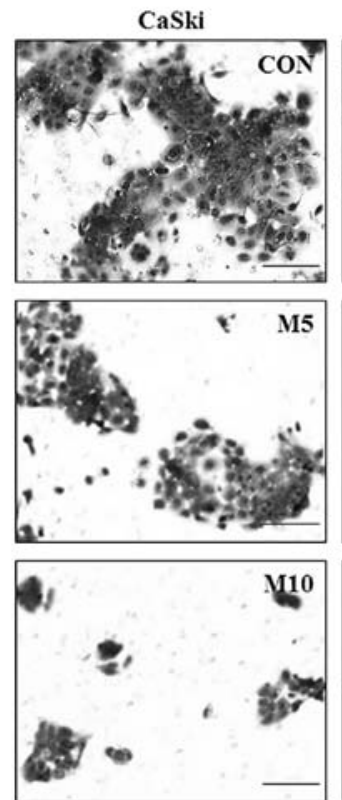
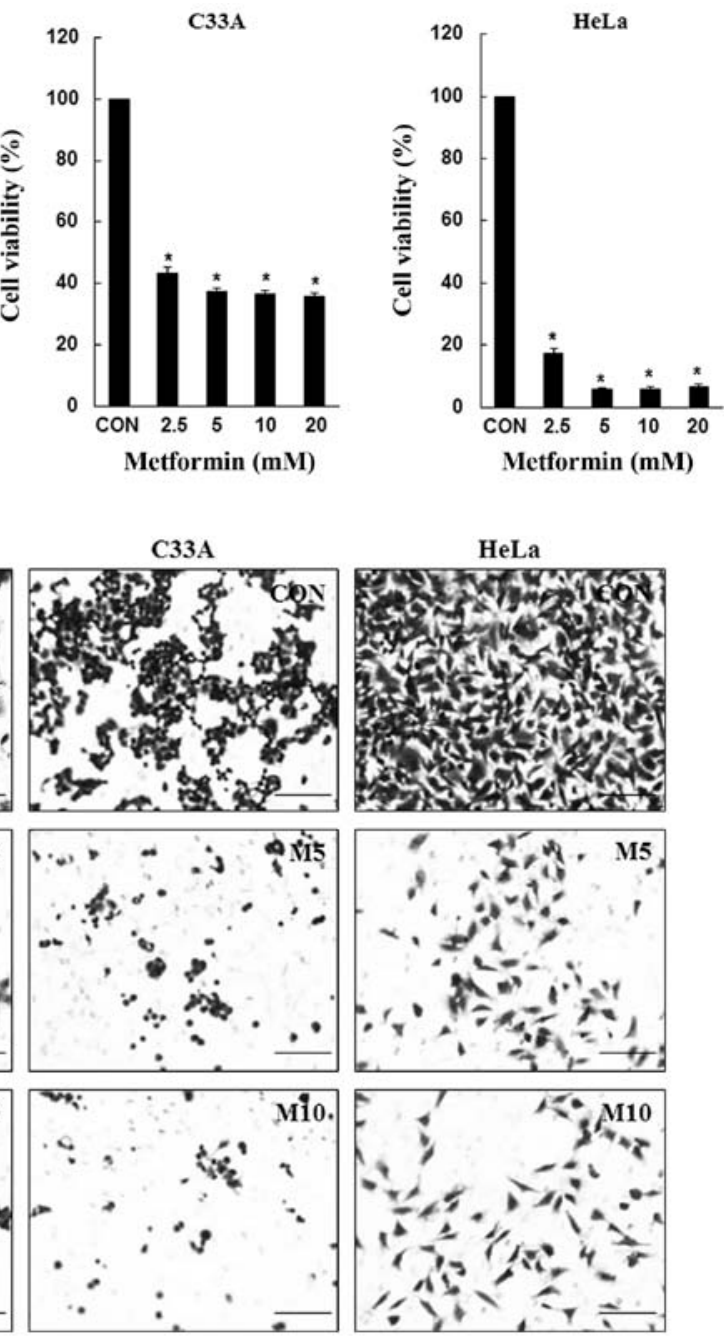

Figure 1. Metformin inhibits cervical cancer cell proliferation and migration. (A) CaSki, C33A and HeLa cells were treated with metformin (0-20 mM) for $48 \mathrm{~h}$. Cell viability was determined by performing the Cell Counting Kit- 8 assay. (B) CaSki, C33A and HeLa cells were treated with metformin (0-10 mM) for $48 \mathrm{~h}$. Cell migration was assessed by performing a Transwell migration assay (scale bar, $200 \mu \mathrm{m}$ ). Data are presented as the mean $\pm \mathrm{SD}$ from three independent experiments. ${ }^{*} \mathrm{P}<0.05$ vs. CON. CON, 0 mM metformin; M5, $5 \mathrm{mM}$ metformin; M10, $10 \mathrm{mM}$ metformin.

overnight at $4^{\circ} \mathrm{C}$ with the following primary antibodies (all 1:1,000): Monoclonal anti-p-AMPKa (Thr172; cat. no. 2535; Cell Signaling Technology, Inc.), monoclonal anti-AMPK $\alpha$ (cat. no. 5832; Cell Signaling Technology, Inc.), polyclonal anti-p-p53 (cat. no. 9284; Cell Signaling Technology, Inc.), polyclonal anti-p53 (cat. no. 9282; Cell Signaling Technology, Inc.), monoclonal anti-Bcl-2 (cat. no. 15071; Cell Signaling Technology, Inc.), monoclonal anti-Bax (cat. no. 5023; Cell Signaling Technology, Inc.), monoclonal anti-cleaved caspase-3 (cat. no. 9664; Cell Signaling Technology, Inc.), monoclonal anti-p-AKT (Ser473; cat. no. 4060; Cell Signaling Technology, Inc.), monoclonal anti-Akt (cat. no. 4298; Cell Signaling Technology, Inc.), monoclonal anti-p-p70S6 kinase (p70S6K; Thr389; cat. no. 9234; Cell Signaling Technology, Inc.), monoclonal anti-p70S6K (cat. no. 2708; Cell Signaling Technology, Inc.), polyclonal anti-Bcl-2 antagonist/killer 1 (Bak; cat. no. GTX100063; GeneTex, Inc.), polyclonal anti-phosphatidylinositol-4,5-bisphosphate 3-kinase catalytic subunit $\alpha$ (PIK3CA; cat. no. NBP2-19804; Novus Biologicals, LLC) and monoclonal anti-GAPDH (cat. no. AC002; ABclonal Biotech Co., Ltd.). Following washing with TBST (Tris-buffered saline, $0.1 \%$ Tween-20), the membranes were incubated with an IgG HRP-conjugated secondary antibody (polyclonal anti-mouse; cat. no. 115-035-003; 1:50,000; Jackson ImmunoResearch Laboratories, Inc.; polyclonal anti-rabbit; cat. no. 31460; 1:100,000; Thermo Fisher Scientific Inc.) for $1 \mathrm{~h}$ at room temperature. Proteins bands were visualized using enhanced chemiluminescence reagent (EMD Millipore). Densitometry was performed using Fusion-Capt Advanced FX7 software (version 16.08a; Labtech International, Ltd.) with GAPDH as the loading control.

Statistical analysis. All experiments were performed at least three times. Data are presented as the mean \pm standard deviation. Comparisons among groups were analyzed using one-way ANOVA followed by Bonferroni's post hoc test using SPSS v22.0 (IBM Corp.). $\mathrm{P}<0.05$ was considered to indicate a statistically significant difference.

\section{Results}

Metformin reduces human cervical cancer cell viability and migration. To determine the inhibitory effects of metformin, CaSki, C33A and HeLa cells were treated with various 
A
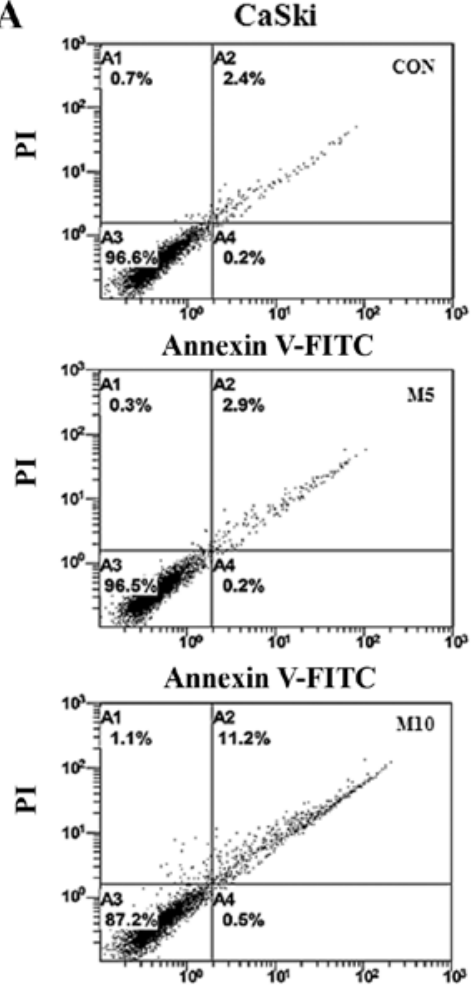

Annexin V-FITC

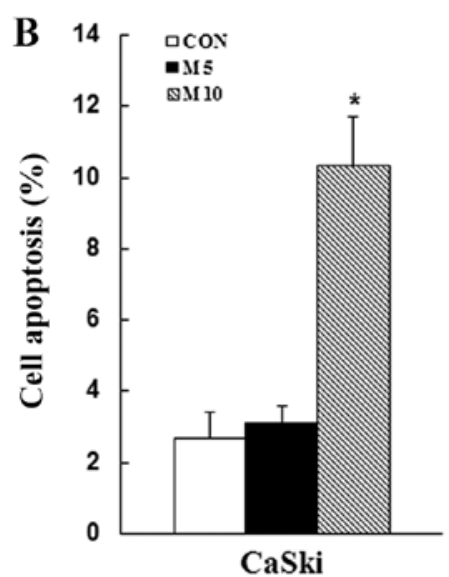

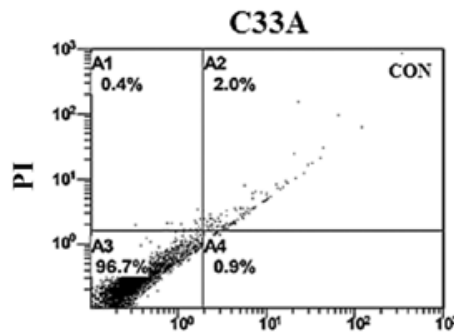
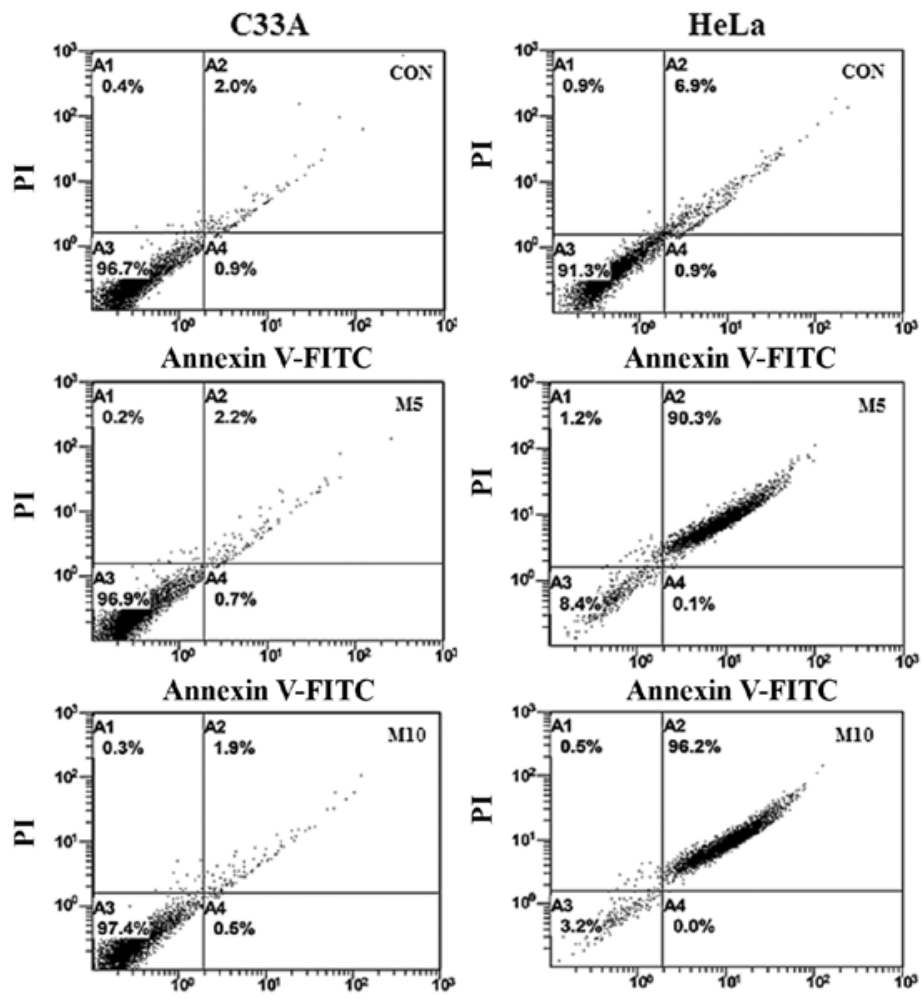

Annexin V-FITC

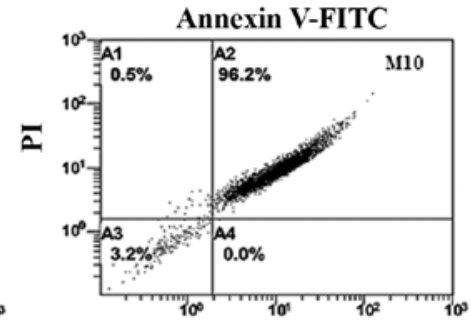

Annexin V-FITC
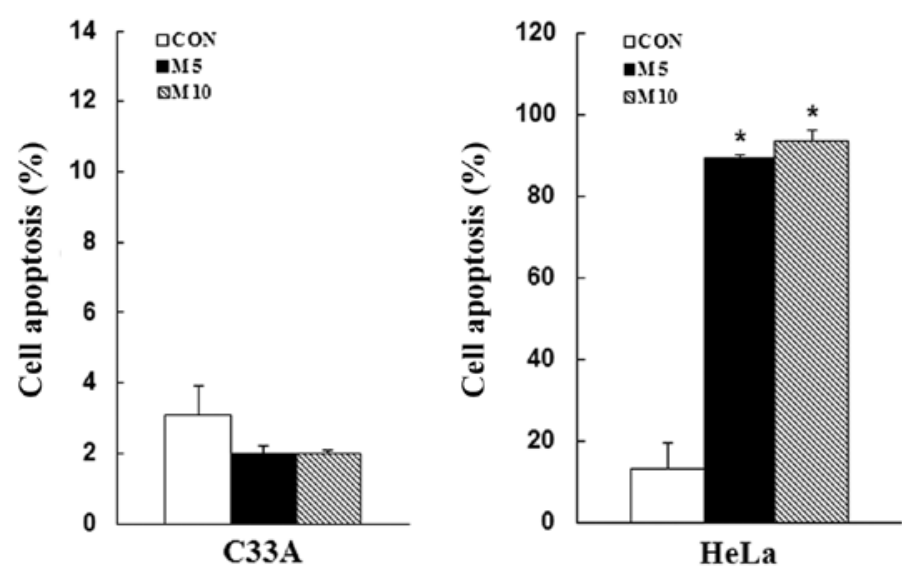

Figure 2. Metformin induces cervical cancer cell apoptosis. CaSki, C33A and HeLa cells were treated with metformin (0, 5 or 10 mM) for 48 h. Cell apoptosis was (A) determined via flow cytometry and (B) quantified. Data are presented as the mean \pm SD from three independent experiments. ${ }^{*}<0.05$ vs. CON. CON, $0 \mathrm{mM}$ metformin; M5, $5 \mathrm{mM}$ metformin; M10, $10 \mathrm{mM}$ metformin.

concentrations of metformin for $48 \mathrm{~h}$, and cell viability was determined using the CCK-8 assay. Compared with the control group, metformin significantly inhibited CaSki, C33A and HeLa cell viability in a dose-dependent manner (Fig. 1A). Similarly, compared with the control group, CaSki, C33A and HeLa cell migration was also markedly decreased following treatment with metformin at $48 \mathrm{~h}$ (Fig. 1B). The results suggested that metformin inhibited cervical cancer cell proliferation and migration.

Metformin induces apoptosis and cell cycle arrest in human cervical cancer cells. To determine whether the inhibitory effects of metformin on cell proliferation were mediated via induction of apoptosis and cell cycle arrest, CaSki, C33A and HeLa cells were stained with Annexin V/PI or PI/RNase, respectively, and then analyzed via flow cytometry. Compared with the control group, metformin treatment increased the number of apoptotic cells in a dose-dependent manner (CaSki cells, $10.3 \pm 1$. vs. $2.7 \pm 0.7 \%$; HeLa cells, $93.8 \pm 2.5$ vs. $13.3 \pm 6.6 \%$ ), although no significant difference was observed in C33A cells (2.0 \pm 0.1 vs. $3.1 \pm 0.8 \%)$ (Fig. 2). Furthermore, compared with the control group, metformin treatment significantly increased the number of CaSki and HeLa cells in the $\mathrm{G}_{2} / \mathrm{M}$ phase, as well as the number of C33A and HeLa cells in the $G_{0} / G_{1}$ phase $(\mathrm{P}<0.05$; Fig. 3$)$. The results indicated that metformin mediated cervical cancer cell death and proliferation via induction of apoptosis and cell cycle arrest.

Metformin activates the AMPK/p53 signaling pathway to mediate the mitochondrial apoptotic pathway. Due to its 
A

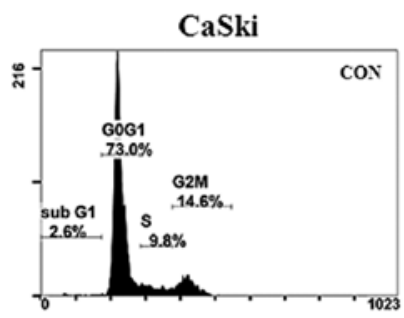

PI
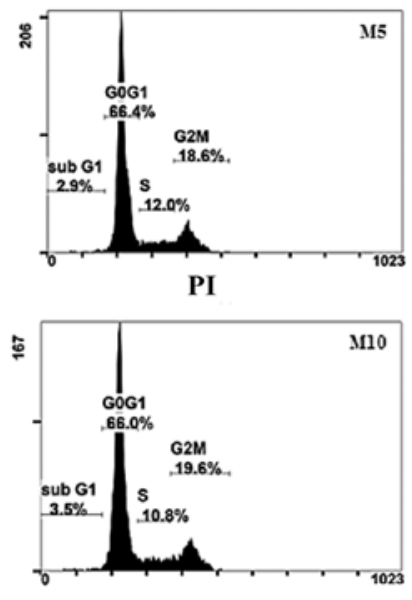

PI

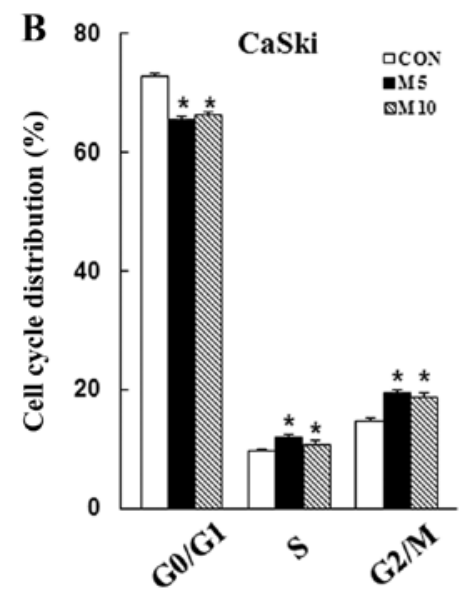

C33A
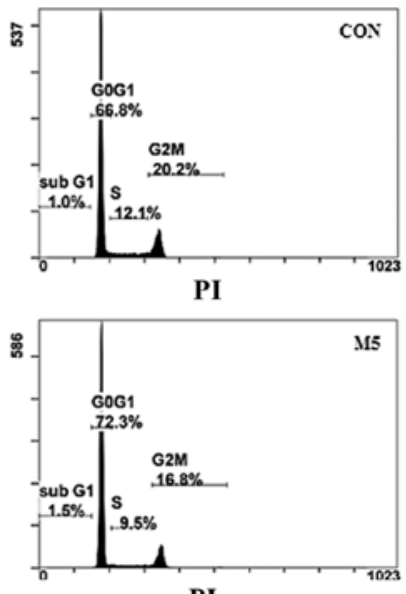

PI

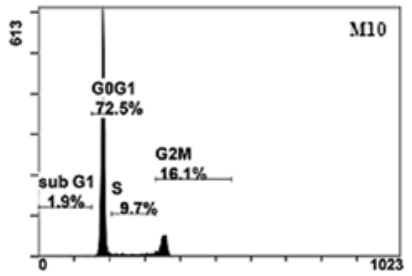

PI

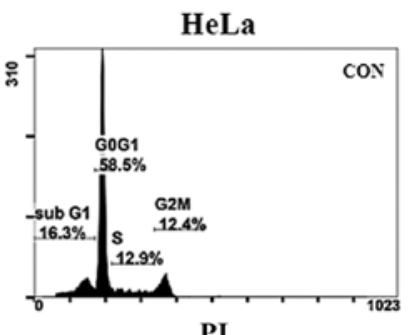

PI
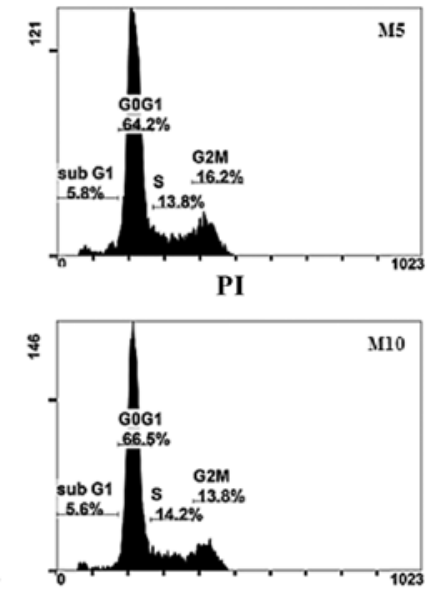

PI
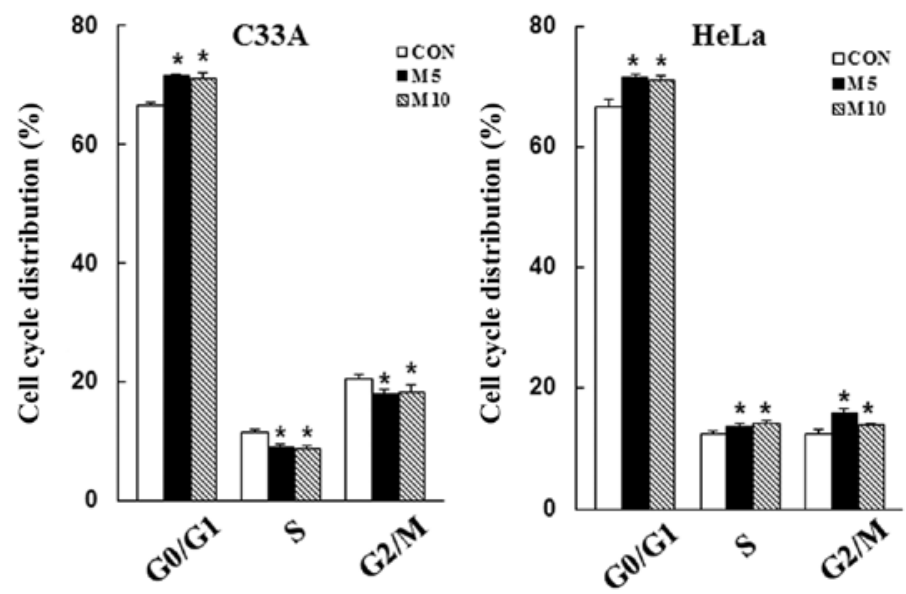

Figure 3. Metformin induces cervical cancer cell cycle arrest. CaSki, C33A and HeLa cells were treated with metformin ( 0,5 or $10 \mathrm{mM})$ for $48 \mathrm{~h}$. Cell cycle phase distribution was (A) determined via flow cytometry and (B) quantified. Data are presented as the mean \pm SD from three independent experiments. ${ }^{*} \mathrm{P}<0.05$ vs. CON. CON, $0 \mathrm{mM}$ metformin; M5, $5 \mathrm{mM}$ metformin; M10, $10 \mathrm{mM}$ metformin.

involvement in apoptotic regulation (41), AMPK/p53 signaling was investigated to determine whether metformin-induced AMPK and p53 activation contributed to apoptosis. In the present study, CaSki, C33A and HeLa cells were treated with 0,5 or $10 \mathrm{mM}$ metformin for $48 \mathrm{~h}$, and the expression levels of AMPK, p53 and apoptosis-related proteins were determined via western blotting. In CaSki and C33A cells, compared with the control group, $5 \mathrm{mM}$ metformin significantly increased the expression levels of p-AMPK, p-p53, Bak and Bax, and significantly decreased the expression levels of the antiapoptotic protein Bcl-2 (Fig. 4). By contrast, p-p53, Bak, Bax and Bcl-2 expression levels were significantly decreased in metformin-treated HeLa cells compared with control cells. Compared with the control group, high dose metformin $(10 \mathrm{mM})$ treatment significantly increased the expression levels of cleaved caspase-3 in CaSki, C33A and HeLa cells. The results indicated that metformin mediated apoptosis via targeting AMPK and mitochondria-mediated caspase-dependent signaling pathways.

Metformin decreases PI3K/AKT signaling. Previous studies have reported that the $\mathrm{PI} 3 \mathrm{~K} / \mathrm{AKT} / \mathrm{mTOR}$ signaling pathway is overactivated in numerous cancer types and its activation may promote cancer cell proliferation and migration, as well as inhibit apoptosis $(42,43)$. In the present study, western blotting was performed to determine the expression levels of PIK3CA, p-AKT and p-p70S6K. Compared with the control group, $10 \mathrm{mM}$ metformin significantly reduced PIK3CA, p-AKT and p-p70S6K expression levels in CaSki, C33A and HeLa cells $(\mathrm{P}<0.05$; Fig. 5). The results suggested that the PI3K/AKT 
A

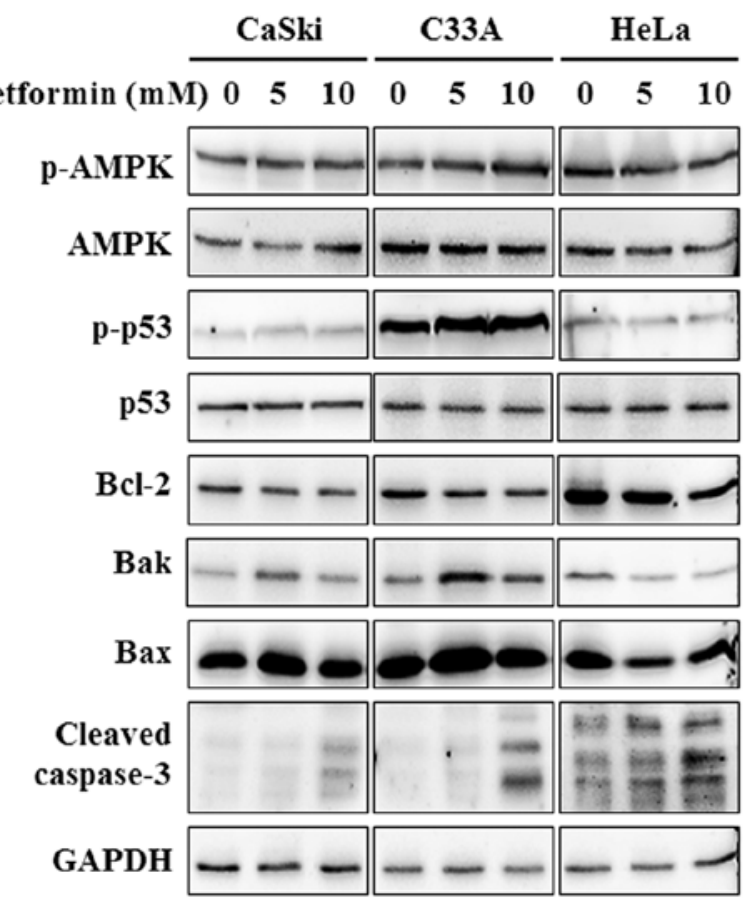

C

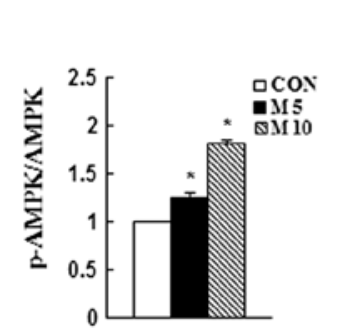

C33A
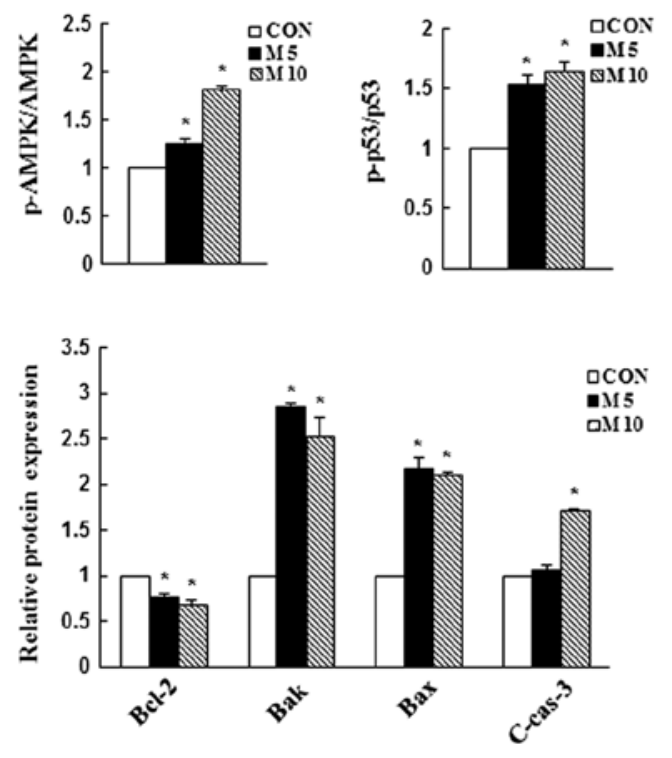

B

CaSki
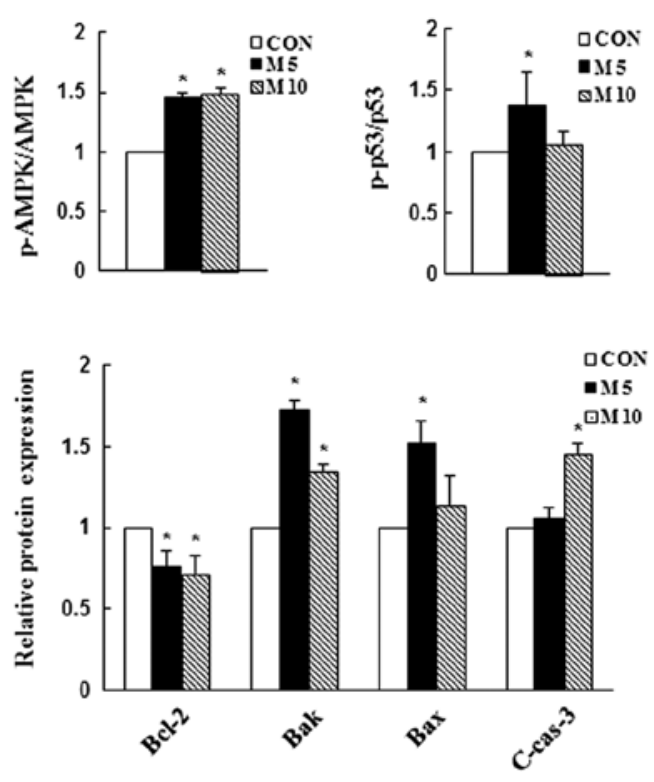

D

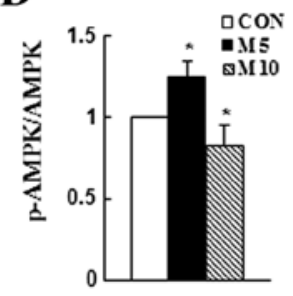

HeLa
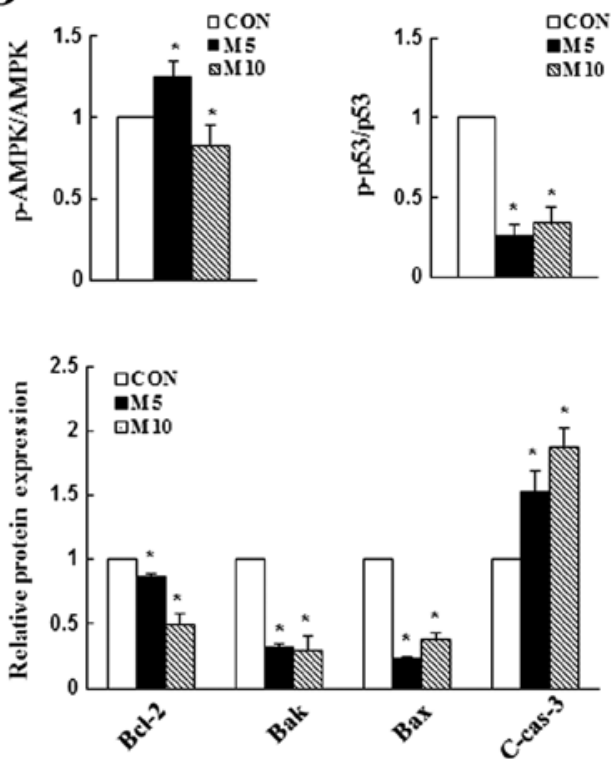

Figure 4. Effect of metformin on AMPK and caspase-dependent apoptosis signaling in cervical cancer cell lines. CaSki, C33A and HeLa cells were treated with metformin $(0,5$ or $10 \mathrm{mM}$ ) for $48 \mathrm{~h}$. p-AMPK, AMPK, p-p53, p53, Bcl-2, Bak, Bax and cleaved caspase-3 protein expression levels were (A) determined via western blotting and semi-quantified in (B) CaSki, (C) C33A and (D) HeLa cells. Data are presented as the mean \pm SD from three independent experiments. "P<0.05 vs. CON. AMPK, AMP-activated protein kinase; p, phosphorylated; Bak, Bcl-2 antagonist/killer 1; CON, 0 mM metformin; M5, 5 mM metformin; M10, 10 mM metformin; C-cas-3, cleaved caspase-3.

signaling pathway might be involved in regulating cellular physiology and apoptosis following metformin treatment.

AMPK signaling pathway activity contributes to metformin-induced cytotoxicity and apoptosis in human cervical cancer cells. To assess whether the AMPK signaling pathway served a key molecular role in metformin-treated cervical cancer cells, CaSki, C33A and HeLa cells were pre-treated with or without 1 or $5 \mu \mathrm{M}$ Compound $\mathrm{C}$ for $2 \mathrm{~h}$, and then treated with or without $10 \mathrm{mM}$ metformin for $48 \mathrm{~h}$. Cell viability and the expression levels of p-AMPK,
AMPK, p-p53, p53, Bcl-2 and cleaved caspase-3 were determined by performing the CCK-8 assay and western blotting, respectively. In CaSki and C33A cells, pre-treatment with Compound $\mathrm{C}$ significantly reversed the effects of metformin on cell viability, and suppressed p-AMPK, p-p53, cleaved caspase-3 and increased Bcl-2 expression levels compared with metformin treatment alone. By contrast, p-AMPK, p-p53 and Bcl-2 expression levels were significantly increased in the metformin + Compound $\mathrm{C}$ group compared with the metformin group in HeLa cells $(\mathrm{P}<0.05$; Fig. 6). The results indicated that metformin enhanced apoptosis by targeting 
A

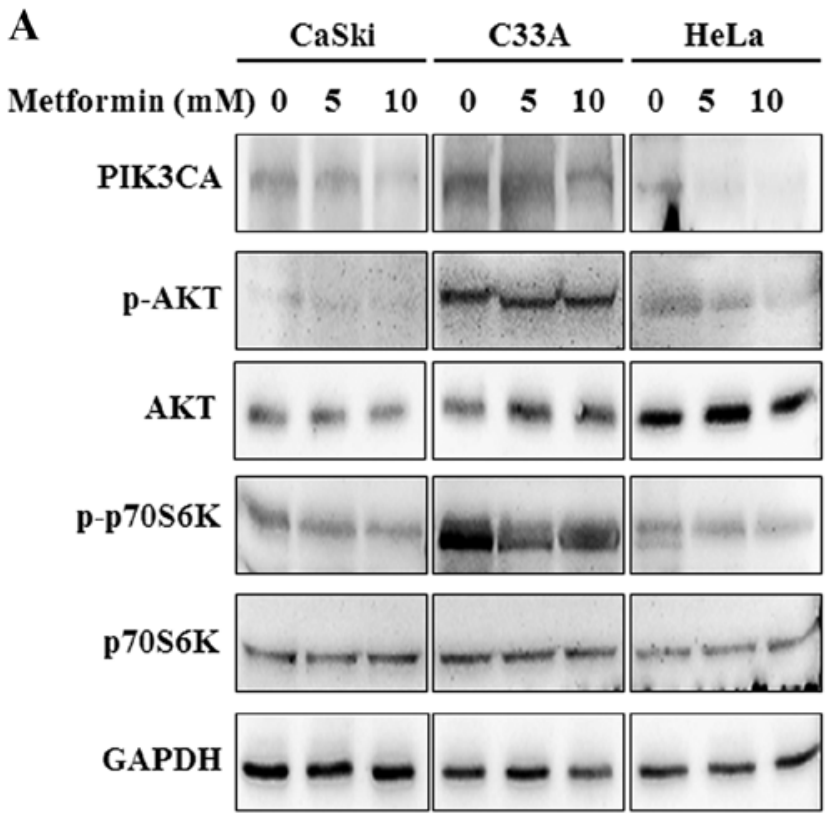

C

C33A
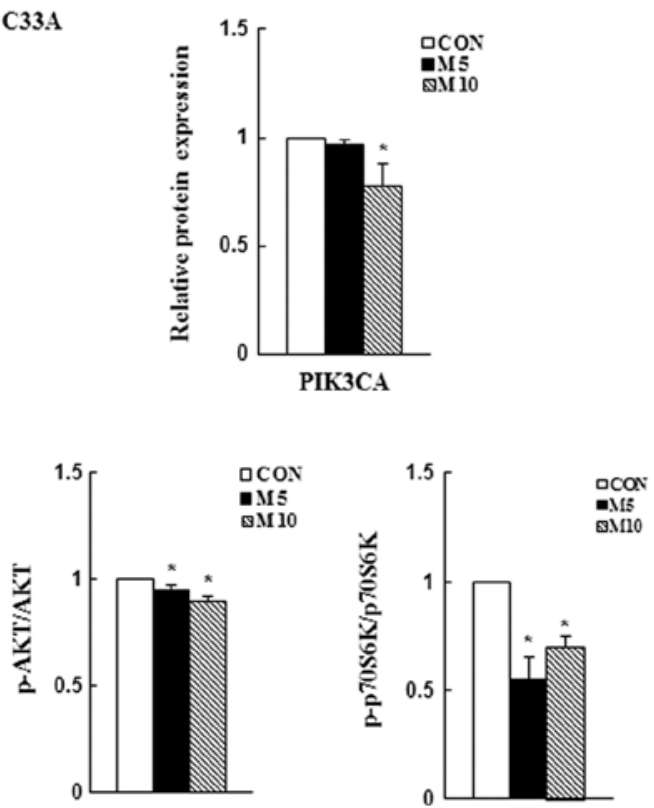

B CaSki
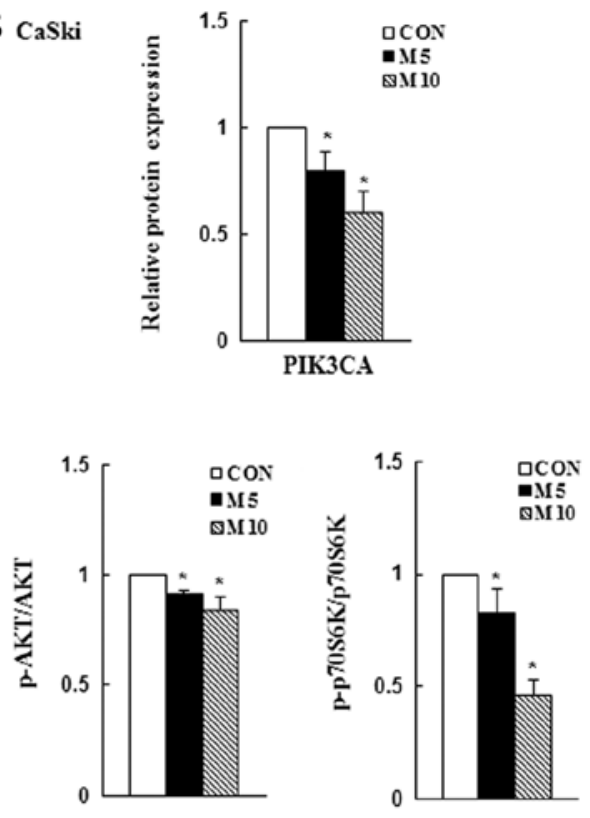

D HeLa
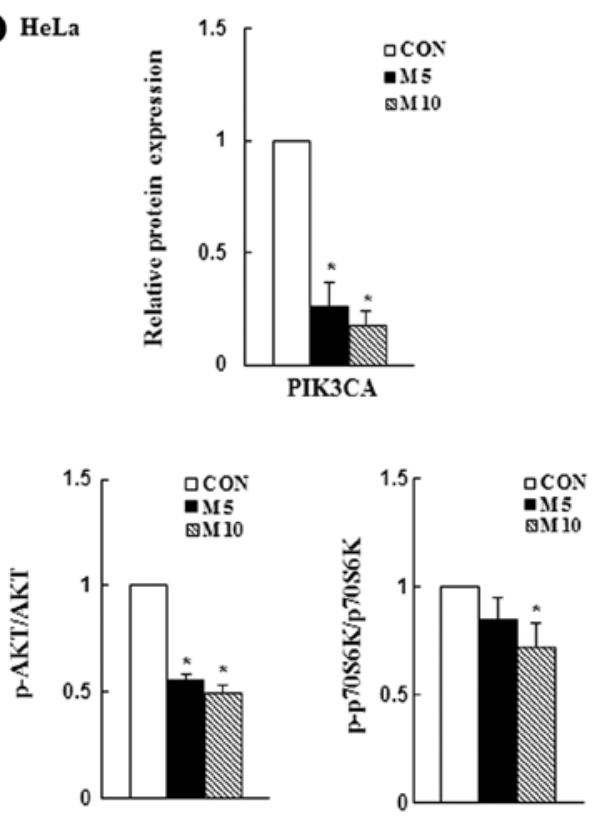

Figure 5. Effects of metformin on PI3K/AKT/mTOR signaling in cervical cancer cell lines. CaSki, C33A and HeLa cells were treated with metformin $(0,5$ or $10 \mathrm{mM}$ ) for $48 \mathrm{~h}$. Protein expression levels of PIK3CA, p-AKT, AKT, p-p70S6K, and p70S6K were (A) determined via western blotting and semi-quantified in (B) CaSki, (C) C33A and (D) HeLa cells. Data are presented as the mean \pm SD from three independent experiments. "P<0.05 vs. CON. p, phosphorylated; PIK3CA, phosphatidylinositol-4,5-bisphosphate 3-kinase catalytic subunit $\alpha$; p70S6K, p70S6 kinase; CON, 0 mM metformin; M5, 5 mM metformin; M10, $10 \mathrm{mM}$ metformin.

the AMPK/p53 signaling pathway in CaSki, C33A and HeLa cells.

\section{Discussion}

Metformin is a widely used antidiabetic drug that has also been shown to reduce the risk of cancer and improve the efficacy of cancer treatment in patients with diabetes $(44,45)$. However, multiple observational studies have demonstrated that metformin displays a similar protective effect and can improve the survival time of non-diabetic patients with cancer $(46,47)$, but the results are controversial. In the present study, CCK-8,
Transwell and flow cytometry assays were performed to evaluate the effects of metformin on cell viability, migration, apoptosis and the cell cycle in human cervical cancer cells, respectively. Western blotting was conducted to quantify protein expression. The results of the present study indicated that metformin significantly reduced human cervical cancer cell viability (CaSki, C33A and HeLa) in a dose-dependent manner (Fig. 1A), which was consistent with previous studies that demonstrated that metformin significantly reduced the viability of thyroid cancer, osteosarcoma, leukemia and bile duct cancer cells by downregulating the expression of the antiapoptotic protein $\mathrm{Bcl}-2$, and upregulating the expression 

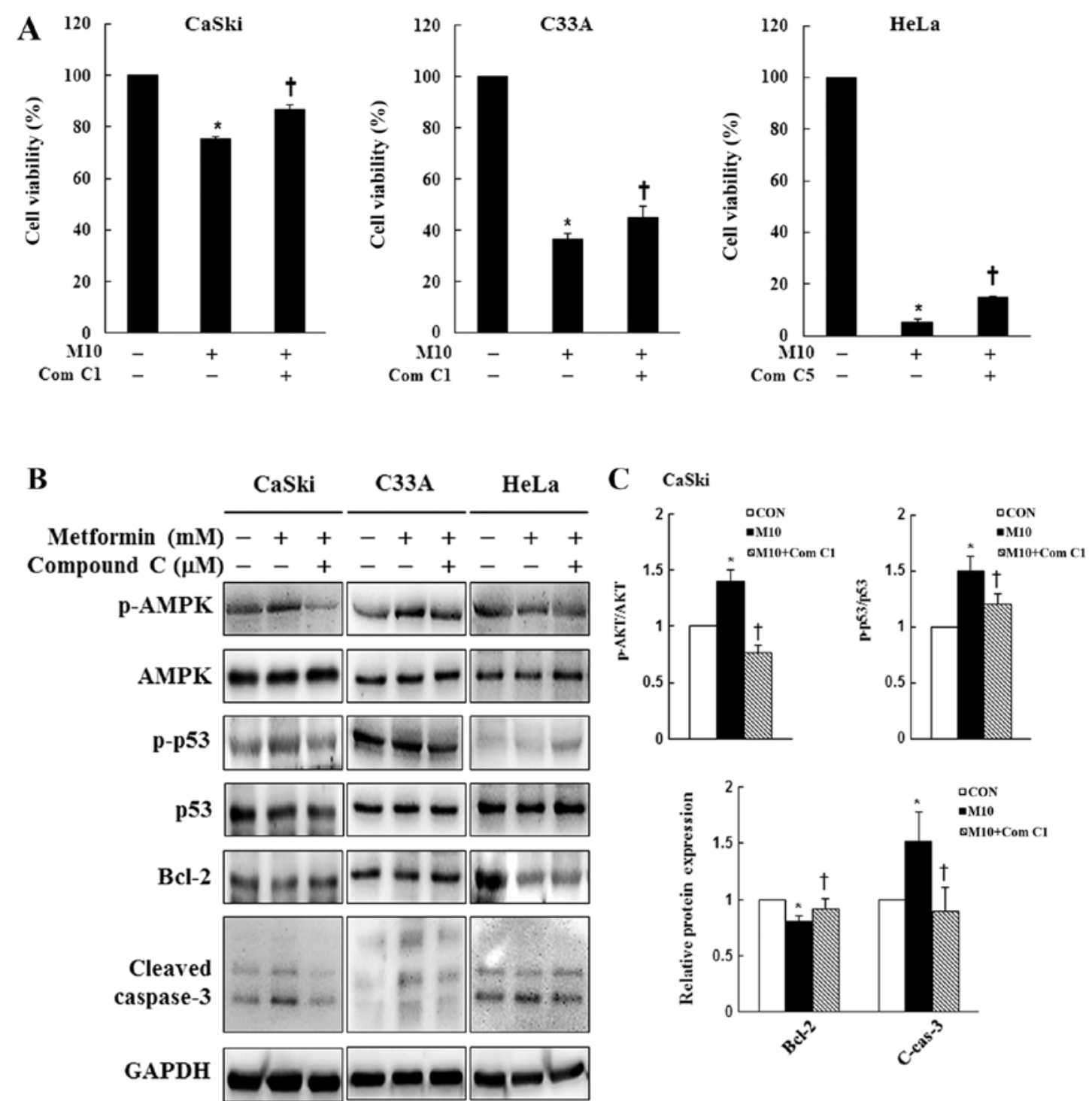

D
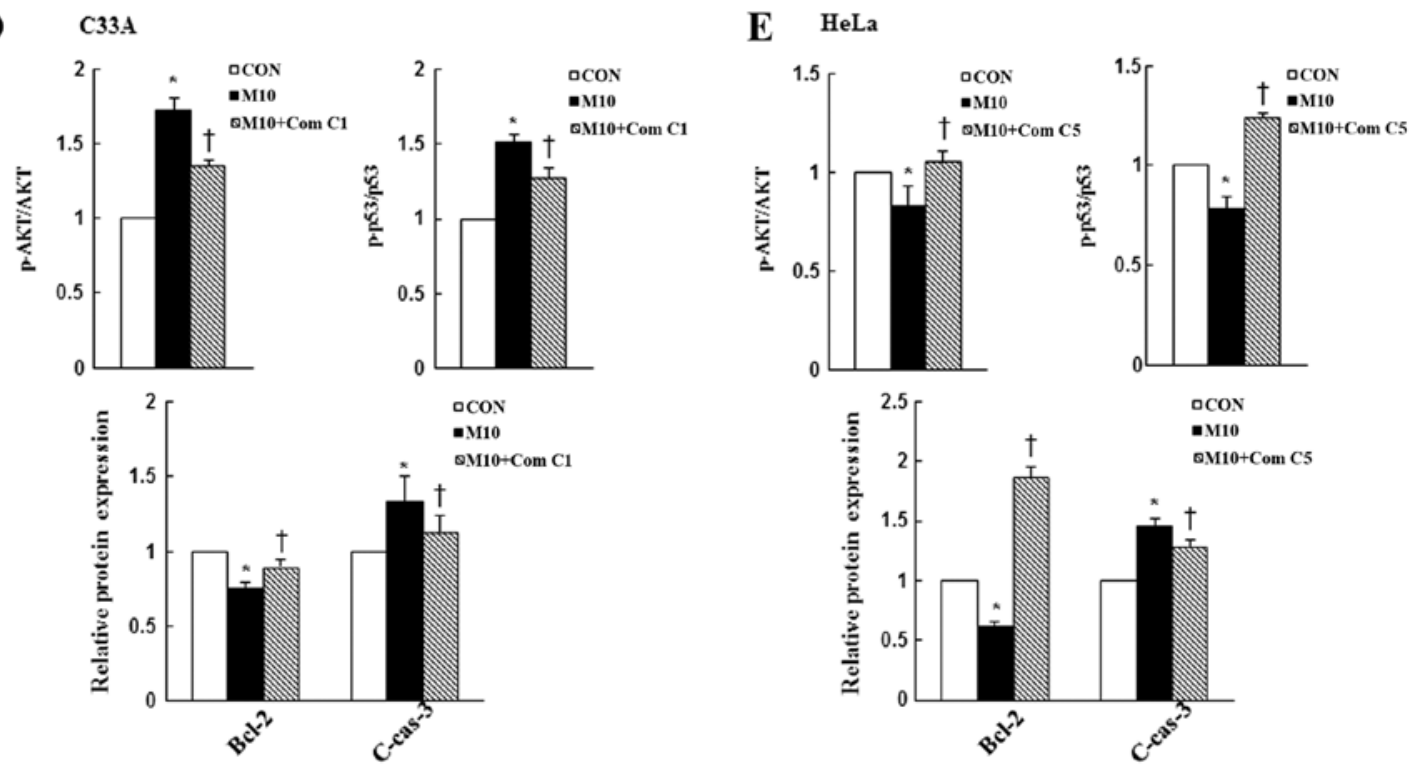

Figure 6. Effects of Compound C on cell viability, AMPK signaling and apoptotic signaling in cervical cancer cell lines. CaSki, C33A and HeLa cells were pre-treated with or without Compound $\mathrm{C}(1$ or $5 \mu \mathrm{M}$; an AMPK inhibitor) for $2 \mathrm{~h}$ and then treated with or without $10 \mathrm{mM}$ metformin for $48 \mathrm{~h}$, the concentration of metformin selected for experiment was based on the cell viability assay test. (A) Cell viability was determined by performing the Cell Counting Kit- 8 assay. Protein expression levels of p-AMPK, AMPK, p-p53, p53, Bcl-2 and cleaved caspase-3 were (B) determined by western blotting and semi-quantified in (C) CaSki, (D) C33A and (E) HeLa cells. Data are presented as the mean \pm SD from three independent experiments. ${ }^{*} \mathrm{P}<0.05$ vs. CON; ${ }^{\circ}<0.05$ vs. M10. AMPK, AMP-activated protein kinase; p, phosphorylated; CON, 0 mM metformin; M10, 10 mM metformin; Com C1, $1 \mu \mathrm{M}$ Compound C; Com C5, $5 \mu \mathrm{M}$ Compound C; C-cas-3, cleaved caspase-3. 
of the proapoptotic proteins Bak and Bax (16,48-50). The present study also indicated that HeLa cells were more sensitive to metformin compared with CaSki and C33A cells, which may be caused by cell-type specificity and mutations in cancer-related genes resulting in resistance to the anti-proliferative effects of metformin. CaSki cells, which are derived from small bowel metastasis, have been reported to possess an integrated human papilloma virus 16 genome (51). C33A cells are human papillomavirus (HPV)-negative human cervical cancer cells that display upregulated expression of oncogenes p53 and retinoblastoma protein (52). HeLa cells are a cervical adenocarcinoma-derived cell line containing integrated HPV-18 DNA and lower levels of p53 expression (53).

Consistent with the results of the present study, Hsieh Li et al (53) reported that metformin significantly induces apoptotic HeLa cell death and reduces p53 expression levels. By contrast, Xiao et al (54) reported that metformin is less effective against HeLa cells and enhances AMPK activation, but does not alter the expression levels of LKB1 or p53. Irie et al (55) also demonstrated that metformin is able to enhance LKB1 phosphorylation, promote AMPK and p53 activation, and inhibit cell cycle progression, resulting in cervical cancer cell death. Therefore, the mechanism underlying metformin-mediated effects on cervical cancer requires further investigation.

In addition, the present study indicated that metformin-induced cytotoxicity occurred via activation of the caspase-dependent apoptotic signaling pathway. Moreover, the results suggested that metformin induced cytotoxicity by promoting cell cycle arrest in the $\mathrm{G}_{2} / \mathrm{M}$ phase and increasing apoptosis in CaSki and HeLa cells, and promoting $\mathrm{G}_{0} / \mathrm{G}_{1}$ phase cell cycle arrest in C33A and HeLa cells. Previous studies have illustrated the effects of metformin on the cell cycle in human osteosarcoma, demonstrating increased K7M2 and MG63 cell numbers in the $\mathrm{G}_{0} / \mathrm{G}_{1}$ phase, and increased $\mathrm{U} 20 \mathrm{~S}$ and $143 \mathrm{~B}$ cell numbers in the $\mathrm{G}_{2} / \mathrm{M}$ phase $(49,56)$. Additionally, metformin has been reported to enhance anticancer effects by arresting human colon carcinoma cells in the $\mathrm{G}_{0} / \mathrm{G}_{1}$ phase (SW480 cells) or the $\mathrm{G}_{2} / \mathrm{M}$ phase (HCT116 p53 ${ }^{-/}$cells) $(57,58)$. The differences among cell lines may be associated with cancer cell line specificity and individual metformin bioavailability.

AMPK is not only a sensor of cellular energetics, but is also a crosstalk protein involved in apoptotic signaling pathways, including the LKB1-AMPK and AMPK/p53 signaling pathways $(41,59)$. The results of the present study revealed that AMPK activation was consistent with increased p-p53 expression following metformin treatment, and that the AMPK inhibitor Compound $\mathrm{C}$ significantly alleviated p53 activation in metformin-treated cells. The aforementioned results indicated that the anticancer effect of metformin was mediated via the AMPK/p53 signaling pathway, although metformin did not induce p53 activation in HeLa cells. Furthermore, the results of the present study were consistent with previous reports that demonstrated that metformin induces the phosphorylation and activation of $\mathrm{p} 53$, which inhibits prostate, melanoma, lymphoma and acute myeloid leukemia cancer cell proliferation (49,60-62). Moreover, metformin can inhibit $\mathrm{p} 53^{-/-}$colorectal cancer cell proliferation both in vitro and in vivo (30). Previous studies have reported that metformin directly decreases the expression levels of endogenous p53 in sensitive cells, which downregulates the expression of target genes, including p21, Bax, Bak and BH3-only proteins (Bid and Bim), ultimately resulting in apoptosis $(53,63,64)$. The results of the aforementioned previous studies were consistent with the results of the present study, which indicated that high-dose metformin (10 mM) induced CaSki cell apoptosis more effectively compared with low-dose metformin $(5 \mathrm{mM})$, despite decreases in p-p53, Bak and Bax expression levels. Therefore, the present study indicated that metformin activated AMPK, inhibiting cervical cancer cell viability in both a p53-dependent and -independent manner.

Metformin displays inhibitory effects on cell proliferation, apoptosis, metastasis, angiogenesis and chemoresistance in various malignancies in vitro and in vivo, including ovarian (65), endometrial (66) and hepatocellular cancer (67). The inhibitory effects of metformin were mediated via activation of the PI3K/AKT/mTOR signaling pathway (65-67). In an earlier study, Storozhuk et al (68) also demonstrated that metformin inhibited tumor growth in non-small cell lung cancer (NSCLC) and xenograft animal models by activating the ATM serine/threonine kinase/AMPK/p53 signaling pathway and inhibiting the AKT/mTOR/eukaryotic translation initiation factor 4E-binding protein 1 signaling pathway, leading to an enhanced radiation response in NSCLC. Likewise, the clinical studies conducted by Dhillon et al (69) and Sayed et al (70) demonstrated that metformin treatment is associated with the improved overall survival of patients with NSCLC. In the present study, compared with the control group, metformin significantly decreased PIK3CA, p-AKT and p-p70S6K expression levels in CaSki, C33A and HeLa cells. The results indicated that metformin-mediated alterations to the PI3K/AKT/mTOR signaling pathway were associated with apoptosis induction in human cervical cancer cells.

In conclusion, the results of the present study suggested that metformin induced apoptosis and cell cycle arrest by modulating the AMPK/p53 and PI3K/AKT/mTOR signaling pathways. Collectively, the results indicated that metformin might serve as a novel therapeutic for human cervical cancer.

The present study had some limitations. First, it focused on the effects of metformin on cell death-related pathways in human cervical cancer cells but further studies should be conducted to elucidate the underlying molecular mechanism of the effects in human cervical cancer cells in more detail. Second, only human cervical cancer cell lines were used; future studies using animal models and patient tissues samples should be conducted to elucidate the mechanism underlying metformin-mediated effects on cervical cancer in vivo. Additional clinical studies are required to assess the safety and clinical efficiency of metformin for cervical cancer treatment.

\section{Acknowledgements}

Not applicable.

\section{Funding}

The present study was supported by the Changhua Christian Hospital Research Foundation (grant nos. 108-CCH-IRP-132 and 108-CCH-IRP-059). 


\section{Availability of data and materials}

The datasets used and/or analyzed during the current study are available from the corresponding author on reasonable request.

\section{Authors' contributions}

YHC and YHH designed the study, prepared the figures and drafted the manuscript. SFY and CKY designed the study. HDT, THC and MCC contributed to the conception of the work, drafted the manuscript and revised it critically for important intellectual content. All authors read and approved the final manuscript.

\section{Ethics approval and consent to participate}

Not applicable.

\section{Patient consent for publication}

Not applicable.

\section{Competing interests}

The authors declare that they have no competing interests.

\section{References}

1. Small W Jr, Bacon MA, Bajaj A, Chuang LT, Fisher BJ, Harkenrider MM, Jhingran A, Kitchener HC, Mileshkin LR, Viswanathan AN and Gaffney DK: Cervical cancer: A global health crisis. Cancer 123: 2404-2412, 2017.

2. Simms KT, Steinberg J, Caruana M, Smith MA, Lew JB, Soerjomataram I, Castle PE, Bray F and Canfell K: Impact of scaled up human papillomavirus vaccination and cervical screening and the potential for global elimination of cervical cancer in 181 countries, 2020-99: A modelling study. Lancet Oncol 20: 394-407, 2019.

3. Ch PN, Gurram L, Chopra S and Mahantshetty U: The management of locally advanced cervical cancer. Curr Opin Oncol 30: 323-329, 2018

4. Rosen VM, Guerra I, McCormack M, Nogueira-Rodrigues A, Sasse A, Munk VC and Shang A: Systematic review and network meta-analysis of bevacizumab plus first-line topotecan-paclitaxel or cisplatin-paclitaxel versus non-bevacizumab-containing therapies in persistent, recurrent, or metastatic cervical cancer. Int J Gynecol Cancer 27: 1237-1246, 2017.

5. Bethesda. SEER Cancer Stat Facts: Cervical Cancer. National Cancer Institute. https://seer.cancer.gov/statfacts/html/cervix. html May 2020.

6. Nathan DM, Buse JB, Davidson MB, Heine RJ, Holman RR, Sherwin R and Zinman B; Professional Practice Committee, American Diabetes Association; European Association for the Study of Diabetes: Management of hyperglycaemia in type 2 diabetes: A consensus algorithm for the initiation and adjustment of therapy. A consensus statement from the American Diabetes Association and the European Association for the study of Diabetes. Diabetologia 49: 1711-1721, 2006.

7. Crawley D, Chandra A, Loda M, Gillett C, Cathcart P, Challacombe B, Cook G, Cahill D, Santa Olalla A, Cahill F, et al: Metformin and longevity (METAL): A window of opportunity study investigating the biological effects of metformin in localised prostate cancer. BMC Cancer 17: 494, 2017.

8. Quinn BJ, Dallos M, Kitagawa H, Kunnumakkara AB, Memmott RM, Hollander MC, Gills JJ and Dennis PA: Inhibition of lung tumorigenesis by metformin is associated with decreased plasma IGF-I and diminished receptor tyrosine kinase signaling. Cancer Prev Res (Phila) 6: 801-810, 2013.

9. El-HaggarSM,El-Shitany NA,MostafaMFandEl-Bassiouny NA: Metformin may protect nondiabetic breast cancer women from metastasis. Clin Exp Metastasis 33: 339-357, 2016.
10. Luo Q, Hu D, Hu S, Yan M, Sun Z and Chen F: In vitro and in vivo anti-tumor effect of metformin as a novel therapeutic agent in human oral squamous cell carcinoma. BMC Cancer 12: 517,2012

11. Hosono K, Endo H, Takahashi H, Sugiyama M, Sakai E, Uchiyama T, Suzuki K, Iida H, Sakamoto Y, Yoneda K, et al: Metformin suppresses colorectal aberrant crypt foci in a short-term clinical trial. Cancer Prev Res (Phila) 3: 1077-1083, 2010.

12. Tseng HW, Li SC and Tsai KW: Metformin treatment suppresses melanoma cell growth and motility through modulation of microRNA expression. Cancers (Basel) 11: 209, 2019.

13. Hwang AL, Haynes K, Hwang WT and Yang YX: Metformin and survival in pancreatic cancer: A retrospective cohort study. Pancreas 42: 1054-1059, 2013.

14. Podhorecka M, Ibanez B and Dmoszyńska A: Metformin-its potential anti-cancer and anti-aging effects. Postepy Hig Med Dosw (Online) 71: 170-175, 2017.

15. Shi WY, Xiao D, Wang L, Dong LH, Yan ZX, Shen ZX, Chen SJ, Chen Y and Zhao WL: Therapeutic metformin/AMPK activation blocked lymphoma cell growth via inhibition of mTOR pathway and induction of autophagy. Cell Death Dis 3: e275, 2012.

16. Wang CF, Zhang G,Zhao LJ, Qi WJ, Li XP, Wang JL and Wei LH: Overexpression of the insulin receptor isoform a promotes endometrial carcinoma cell growth. PLoS One 8: e69001, 2013.

17. He Y, Cao L, Wang L, Liu L, Huang Y and Gong X: Metformin inhibits proliferation of human thyroid cancer TPC-1 cells by decreasing LRP2 to suppress the JNK pathway. Onco Targets Ther 13: 45-50, 2020.

18. Ling S, Xie H, Yang F, Shan Q, Dai H, Zhuo J, Wei X, Song P, Zhou L, Xu X and Zheng S: Metformin potentiates the effect of arsenic trioxide suppressing intrahepatic cholangiocarcinoma: Roles of p38 MAPK, ERK3, and mTORC1. J Hematol Oncol 10: 59, 2017.

19. Vazquez-Martin A, Oliveras-Ferraros C and Menendez JA: The antidiabetic drug metformin suppresses her2 (erbb-2) oncoprotein overexpression via inhibition of the mtor effector p70s6k1 in human breast carcinoma cells. Cell Cycle 8: 88-96, 2009.

20. Saber S, Ghanim AMH, El-Ahwany E and El-Kader EMA: Novel complementary antitumour effects of celastrol and metformin by targeting $\mathrm{I} \kappa \mathrm{B} \kappa \mathrm{B}$, apoptosis and NLRP3 inflammasome activation in diethylnitrosamine-induced murine hepatocarcinogenesis. Cancer Chemother Pharmacol 85: 331-343, 2020.

21. Kowall B, Stang A, Rathmann W and Kostev K: No reduced risk of overall, colorectal, lung, breast, and prostate cancer with metformin therapy in diabetic patients: Database analyses from Germany and the UK. Pharmacoepidemiol Drug Saf 24: $865-874,2015$.

22. Iliopoulos D, Hirsch HA and Struhl K: Metformin decreases the dose of chemotherapy for prolonging tumor remission in mouse xenografts involving multiple cancer cell types. Cancer Res 71: 3196-3201, 2011.

23. Tyszka-Czochara M, Lasota M and Majka M: Caffeic acid and metformin inhibit invasive phenotype induced by TGF- $\beta 1$ in $\mathrm{C}-4 \mathrm{I}$ and HTB-35/SiHa human cervical squamous carcinoma cells by acting on different molecular targets. Int J Mol Sci 19: 266, 2018.

24. Xia C, Chen R, Chen J, Qi Q, Pan Y, Du L, Xiao G and Jiang S: Combining metformin and nelfinavir exhibits synergistic effects against the growth of human cervical cancer cells and xenograft in nude mice. Sci Rep 7: 43373, 2017.

25. Pollak MN: Investigating metformin for cancer prevention and treatment: The end of the beginning. Cancer Discov 2: 778-790, 2012.

26. Pollak M: The insulin and insulin-like growth factor receptor family in neoplasia: An update. Nat Rev Cancer 12: 159-169, 2012.

27. Shackelford DB and Shaw RJ: The LKB1-AMPK pathway: Metabolism and growth control in tumour suppression. Nat Rev Cancer 9: 563-575, 2009.

28. Foretz M, Carling D, Guichard C, Ferre P and Foufelle F: AMP-activated protein kinase inhibits the glucose-activated expression of fatty acid synthase gene in rat hepatocytes. J Biol Chem 273: 14767-14771, 1998.

29. Choi YK and Park KG: Metabolic roles of AMPK and metformin in cancer cells. Mol Cells 36: 279-287, 2013.

30. Buzzai M, Jones RG, Amaravadi RK, Lum JJ, DeBerardinis RJ, Zhao F, Viollet B and Thompson CB: Systemic treatment with the antidiabetic drug metformin selectively impairs p53-deficient tumor cell growth. Cancer Res 67: 6745-6752, 2007. 
31. Armando RG, Mengual Gómez DL and Gomez DE: New drugs are not enough-drug repositioning in oncology: An update. Int J Oncol 56: 651-684, 2020.

32. Datta SR, Brunet A and Greenberg ME: Cellular survival: A play in three Akts. Genes Dev 13: 2905-2927, 1999.

33. Nitulescu GM,De Venter MV,Nitulescu G, Ungurianu A, Juzenas $P$, Peng Q, Olaru OT, Grădinaru D, Tsatsakis A, Tsoukalas D, et al: The Akt pathway in oncology therapy and beyond (Review). Int J Oncol 53: 2319-2331, 2018.

34. Bellacosa A, Testa JR, Moore R and Larue L: A portrait of AKT kinases: Human cancer and animal models depict a family with strong individualities. Cancer Biol Ther 3: 268-275, 2004.

35. Cheng JQ, Lindsley CW, Cheng GZ, Yang H and Nicosia SV: The Akt/PKB pathway: Molecular target for cancer drug discovery. Oncogene 24: 7482-7492, 2005

36. Shan ZZ, Chen PN, Wang F, Wang J and Fan QX: Expression of P-EGFR and P-Akt protein in esophageal squamous cell carcinoma and its prognosis. Oncol Lett 14: 2859-2863, 2017.

37. Yu X, Yuan Y, Zhi X, Teng B, Chen X, Huang Q, Chen Y, Guan Z and Zhang Y: Correlation between the protein expression of A-kinase anchor protein 95, cyclin D3 and AKT and pathological indicators in lung cancer tissues. Exp Ther Med 10: 1175-1181, 2015.

38. Yang SX, Costantino JP, Kim C, Mamounas EP, Nguyen D, Jeong JH, Wolmark N, Kidwell K, Paik S and Swain SM: Akt phosphorylation at Ser473 predicts benefit of paclitaxel chemotherapy in node-positive breast cancer. J Clin Oncol 28: 2974-2981, 2010.

39. Lu C and Shervington A: Chemoresistance in gliomas. Mol Cell Biochem 312: 71-80, 2008.

40. Jacobsen K, Bertran-Alamillo J, Molina MA, Teixidó C, Karachaliou N, Pedersen MH, Castellví J, Garzón M, Codony-Servat C, Codony-Servat J, et al: Convergent Akt activation drives acquired EGFR inhibitor resistance in lung cancer. Nat Commun 8: 410, 2017.

41. Nieminen AI, Eskelinen VM, Haikala HM, Tervonen TA, Yan Y Partanen JI and Klefström J: Myc-induced AMPK-phospho p53 pathway activates Bak to sensitize mitochondrial apoptosis. Proc Natl Acad Sci USA 110: E1839-E1848, 2013.

42. LoPiccolo J, Blumenthal GM, Bernstein WB and Dennis PA: Targeting the PI3K/Akt/mTOR pathway: Effective combinations and clinical considerations. Drug Resist Updat 11: 32-50, 2008

43. Li Z, Dong H, Li M, Wu Y, Liu Y, Zhao Y, Chen X and Ma M: Honokiol induces autophagy and apoptosis of osteosarcoma through PI3K/Akt/mTOR signaling pathway. Mol Med Rep 17: 2719-2723, 2018

44. Lee MS, Hsu CC, Wahlqvist ML, Tsai HN, Chang YH and Huang YC: Type 2 diabetes increases and metformin reduces total, colorectal, liver and pancreatic cancer incidences in Taiwanese: A representative population prospective cohort study of 800,000 individuals. BMC Cancer 11: 20, 2011

45. Evans JM, Donnelly LA, Emslie-Smith AM, Alessi DR and Morris AD: Metformin and reduced risk of cancer in diabetic patients. BMJ 330: 1304-1305, 2005.

46. Chen K, Li Y, Guo Z, Zeng Y, Zhang W and Wang H: Metformin: Current clinical applications in nondiabetic patients with cancer. Aging (Albany NY) 12: 3993-4009, 2020.

47. Quinn BJ, Kitagawa H, Memmott RM, Gills JJ and Dennis PA: Repositioning metformin for cancer prevention and treatment Trends Endocrinol Metab 24: 469-480, 2013.

48. Li B, Zhou P, Xu K, Chen T, Jiao J, Wei H, Yang X, Xu W, Wan W and Xiao J: Metformin induces cell cycle arrest, apoptosis and autophagy through ROS/JNK signaling pathway in human osteosarcoma. Int J Biol Sci 16: 74-84, 2020.

49. Zhou X, Kuang Y, Liang S and Wang L: Metformin inhibits cell proliferation in SKM-1 cells via AMPK-mediated cell cycle arrest. J Pharmacol Sci 141: 146-152, 2019.

50. Lee J, Hong EM, Kim JH, Jung JH, Park SW, Koh DH, Choi MH, Jang HJ and Kae SH: Metformin induces apoptosis and inhibits proliferation through the AMP-activated protein kinase and insulin-like growth factor 1 receptor pathways in the bile duct cancer cells. J Cancer 10: 1734-1744, 2019.

51. Pater MM and Pater A: Human papillomavirus types 16 and 18 sequences in carcinoma cell lines of the cervix. Virology 145 313-318, 1985.

52. Donat U, Rother J, Schäfer S, Hess M, Härtl B, Kober C, Langbein-Laugwitz J, Stritzker J, Chen NG, Aguilar RJ, et al: Characterization of metastasis formation and virotherapy in the human C33A cervical cancer model. PLoS One 9: e98533, 2014.

53. Hsieh Li SM, Liu ST, Chang YL, Ho CL and Huang SM: Metformin causes cancer cell death through downregulation of p53-dependent differentiated embryo chondrocyte 1. J Biomed Sci 25: 81, 2018 .
54. Xiao X, He Q, Lu C, Werle KD, Zhao RX, Chen J, Davis BC, Cui R, Liang J and Xu ZX: Metformin impairs the growth of liver kinase B1-intact cervical cancer cells. Gynecol Oncol 127: 249-255, 2012

55. Irie H, Banno K, Yanokura M, Iida M, Adachi M, Nakamura K, Umene K, Nogami Y, Masuda K, Kobayashi Y, et al: Metformin: A candidate for the treatment of gynecological tumors based on drug repositioning. Oncol Lett 11: 1287-1293, 2016.

56. Zhao B, Luo J, Wang Y, Zhou L, Che J, Wang F, Peng S, Zhang G and Shang P: Metformin suppresses self-renewal ability and tumorigenicity of osteosarcoma stem cells via reactive oxygen species-mediated apoptosis and autophagy. Oxid Med Cell Longev 2019: 9290728, 2019.

57. Zhou XZ, Xue YM, Zhu B and Sha JP: Effects of metformin on proliferation of human colon carcinoma cell line SW-480. Nan Fang Yi Ke Da Xue Xue Bao 30: 1935-1938, 1942, 2010 (In Chinese).

58. Kamarudin MNA, Sarker MMR, Zhou JR and Parhar I: Metformin in colorectal cancer: Molecular mechanism, preclinical and clinical aspects. J Exp Clin Cancer Res 38: 491, 2019.

59. Shaw RJ, Kosmatka M, Bardeesy N, Hurley RL, Witters LA, DePinho RA and Cantley LC: The tumor suppressor LKB1 kinase directly activates AMP-activated kinase and regulates apoptosis in response to energy stress. Proc Natl Acad Sci USA 101: 3329-3335, 2004.

60. Ben Sahra I, Laurent K, Giuliano S, Larbret F, Ponzio G, Gounon P, Le Marchand-Brustel Y, Giorgetti-Peraldi S, Cormont M, Bertolotto C, et al: Targeting cancer cell metabolism: The combination of metformin and 2-deoxyglucose induces p53-dependent apoptosis in prostate cancer cells. Cancer Res 70: $2465-2475,2010$

61. Cerezo M, Tichet M, Abbe P, Ohanna M, Lehraiki A, Rouaud F, Allegra M, Giacchero D, Bahadoran P, Bertolotto C, et al: Metformin blocks melanoma invasion and metastasis development in AMPK/p53-dependent manner. Mol Cancer Ther 12: $1605-1615,2013$

62. Singh AR, Gu JJ, Zhang Q, Torka P, Sundaram S, Mavis C and Hernandez-Ilizaliturri FJ: Metformin sensitizes therapeutic agents and improves outcome in pre-clinical and clinical diffuse large B-cell lymphoma. Cancer Metab 8: 10, 2020.

63. Chipuk JE, Kuwana T, Bouchier-Hayes L, Droin NM, Newmeyer DD, Schuler M and Green DR: Direct activation of Bax by $\mathrm{p} 53$ mediates mitochondrial membrane permeabilization and apoptosis. Science 303: 1010-1014, 2004.

64. Chang YL, Lee HJ, Liu ST, Lin YS, Chen TC, Hsieh TY, Huang HS and Huang SM: Different roles of p53 in the regulation of DNA damage caused by1,2-heteroannelated anthraquinones and doxorubicin. Int J Biochem Cell Biol 43: 1720-1728, 2011.

65. Fu YL, Zhang QH, Wang XW and $\mathrm{He} \mathrm{H}$ : Antidiabetic drug metformin mitigates ovarian cancer SKOV3 cell growth by triggering G2/M cell cycle arrest and inhibition of m-TOR/PI3K/Akt signaling pathway. Eur Rev Med Pharmacol Sci 21: 1169-1175, 2017

66. Zhao Y, Sun H, Feng M, Zhao J, Zhao X, Wan Q and Cai D: Metformin is associated with reduced cell proliferation in human endometrial cancer by inbibiting PI3K/AKT/mTOR signaling. Gynecol Endocrinol 34: 428-432, 2018.

67. Zhang HH, Zhang Y, Cheng YN, Gong FL, Cao ZQ, Yu LG and Guo XL: Metformin incombination with curcumin inhibits the growth, metastasis, and angiogenesis of hepatocellular carcinoma in vitro and in vivo. Mol Carcinog 57: 44-56, 2018.

68. Storozhuk Y, Hopmans SN, Sanli T, Barron C, Tsiani E, Cutz JC, Pond G, Wright J, Singh G and Tsakiridis T: Metformin inhibits growth and enhances radiation response of non-small cell lung cancer (NSCLC) through ATM and AMPK. Br J Cancer 108: 2021-2032, 2013.

69. Dhillon SS, Groman A, Meagher A, Demmy T, Warren GW and Yendamuri S: Metformin and not diabetes influences the survival of resected early stage NSCLC patients. J Cancer Sci Ther 6: 217-222, 2014.

70. Sayed R, Saad AS, ElWakeel L, Elkholy E and Badary O: Metformin addition to chemotherapy in stage IV non-small cell lung cancer: An open label randomized controlled study. Asian Pac J Cancer Prev 16: 6621-6626, 2015.

This work is licensed under a Creative Commons Attribution-NonCommercial-NoDerivatives 4.0 International (CC BY-NC-ND 4.0) License. 